\title{
AKTIVITAS ANTIOKSIDAN MIKROKAPSUL EKSTRAK ETANOL KAPANG ONCOM MERAH (Neurospora sp)
}

\author{
[Antioxydant Activity of Microcapsul Etanol Extract of Neurospora sp] \\ Aini Auliana Amar ${ }^{1}$, Syaiful Bahri ${ }^{{ }^{\star}}$, Mappiratu ${ }^{1}$ \\ 1) Jurusan Kimia, Fakultas MIPA, Universitas Tadulako \\ Jl. Soekarno Hatta, Kampus Bumi Tadulako Tondo Palu, Telp. 0451- 422611
}

*)Corresponding Author: caniagos@yahoo.com

Diterima 18 April 2018, Disetujui 23 Mei 2018

\begin{abstract}
This study aims to determine the antioxidant activity and storage stability of microcapsul of ethanol extract red pie mold spores (Neurospora Sp) at room temperature for 4 weeks. The coating used is maltodextrin. Ratio variation between maltodextrin and ethanol extract of red pie mold is $1: 0.5 ; 1$ : $0.75 ; 1: 1 ; 1: 1.25 ; 1: 5(\mathrm{w} / \mathrm{v})$. The result showed that the highest antioxidant activity was at ratio $1: 1$ ( $w / v)$, in addition, the stability of microcapsul of extract is better than the extract without microencapsulated.
\end{abstract}

Keywords : antioxidant, microcapsule, red pie mold spores, stability.

\begin{abstract}
ABSTRAK
Penelitian ini bertujuan untuk mengetahui aktivitas antioksidan dan stabilitas mikrokapsul ekstrak etanol spora kapang oncom merah (Neurospora sp) pada penyimpanan suhu ruang selama 4 minggu. Penyalut yang digunakan adalah maltodekstrin. Variasi perbandingan antara maltodekstrin dengan ekstrak etanol kapang oncom merah adalah $1: 0,5 ; 1: 0,75 ; 1: 1 ; 1: 1,25 ; 1: 5(\mathrm{~b} / \mathrm{v})$. Hasil yang didapatkan adalah aktivitas antioksidan tertinggi didapatkan pada perbandingan 1:1 (b/v), dan mikrokapsul ekstrak etanol spora kapang oncom merah lebih stabil pada penyimpanan suhu ruang dibandingkan ekstrak tanpa mikroenkapsulasi.
\end{abstract}

Kata kunci: antioksidan, mikrokapsul, kapang oncom merah, stabilitas. 


\section{LATAR BELAKANG}

Oncom adalah makanan khas Jawa Barat yang memiliki nilai gizi yang tinggi dan harga murah sehingga diminati masyarakat luas. Adanya proses fermentasi pada oncom akan mengakibatkan senyawa kimia kompleks akan terurai menjadi senyawa kimia dengan struktur yang lebih sederhana. Senyawa yang lebih sederhana tersebut akan lebih mudah dicerna oleh tubuh dan selanjutnya digunakan oleh tubuh pada proses metabolism (Hesseltine, 1961). Oleh karena itu, oncom merupakan sumber gizi yang potensial bagi masyarakat.

Menurut Saono (1986), kapang yang berperan dalam proses fermentasi oncom merah adalah Neurospora $s p$, dan oncom hitam adalah Rhizopus Oligosporus. Kapang Neurospora $s p$ adalah jenis kapang yang memiliki waktu generasi yang pendek dan miseliumnya terdiri dari hifa yang bercabang dan menjulang, serta mudah dikenali dari konidia yang berwarna jingga atau merah (Gusnidar et al., 2011). Kapang Neurospora Sp dapat dengan mudah tumbuh pada berbagai macam media, dan dapat meningkatkan protein serta dapat menghasilkan karotenoid pada media dimana dia tumbuh.

Analisis FTIR pada Neurospora ampas tahu memberikan petunjuk bahwa kapang oncom merah memproduksi xantofil dan karoten, keduanya mempunyai aktivitas antioksidan dan dapat dipisahkan menggunakan pelarut etanol dan heksana. Pelarut etanol akan melarutkan xantofil, sedangkan pelarut heksana akan melarutkan karoten (Asma, 2016). Persentasi produksi oleh Neurospora adalah 5\% xantofil dan 95\% karoten (Mappiratu, 1990).

Karotenoid sebagai antioksidan berperan mencegah timbulnya radikal bebas dalam tubuh, penyebab beberapa jenis kanker dan jantung (Kusbandari dan Susanti, 2017). Asma (2016) menemukan aktivitas antioksidan kelompok xantofil relative lebih tinggi $\left(12,72 \%\right.$ inhibisi, $I_{50}$ 809,65 ppm) dibandingkan kelompok karoten dengan nilai persen inhibisi 10,72 $\%$ dan nilai $I_{50} 2.894,29$ ppm.

Karotenoid merupakan senyawa nonpolar yang tidak larut dalam air sehingga menyulitkan penggunaannya pada proses formulasi produk pangan. Selain itu, karotenoid bersifat peka terhadap oksigen, panas dan cahaya dikarenakan karotenoid sangat mudah teroksidasi, sehingga membatasi penggunaannya dalam produk pangan, pangan fungsional dan farmasi (Yuan et al., 2008). Salah satu cara melindungi karotenoid dari kerusakan dan penurunan kualitasnya adalah dengan teknik mikroenkapsulasi.

\section{METODE PENELITIAN}

\section{Bahan dan Peralatan}

Alat-alat yang digunakan pada penelitian ini, ialah rak fermentasi, kuas, sheaker (mesin kocok), rotary vacuum evaporator, neraca analitik (Ohaus Corp. 
Pine Brook), lemari pendingin, tabung nitrogen, sprektrofotemeter UV-VIS (Perkinelmer), dan alat-alat gelas yang umum digunakan dalam Laboratorium Kimia.

Bahan-bahan yang digunakan pada penelitian ini, ialah tongkol jagung muda, Inokulum kapang oncom merah (Neurospora sp), etanol 95\%, methanol, maltodekstrin, heksan, aseton dan DPPH.

\section{Prosedur Penelitian}

\section{Produksi Spora Kapang}

Produksi spora kapang oncom merah mengikuti cara Kenyamu et al. (2014), yaitu tongkol jagung muda disortir, ditimbang kemudian disterilkan dengan cara dikukus selama 1 jam. Tongkol jagung yang telah dikukus disimpan di atas rak dan diinokulasi dengan inokulum kapang oncom merah, untuk menjaga kelembaban, rak ditutup dengan plastik dan difermentasi selama 4 hari. Spora kapang diambil dengan kuas, ditimbang dan disimpan dalam kantong plastik sebelum diekstrak dengan pelarut etanol.

\section{Ekstraksi (Mappiratu, 1990)}

Ekstraksi spora kapang oncom merah dilakukan menggunakan pengekstrak etanol 95\%. Spora kapang oncom merah dimasukkan ke dalam erlenmeyer selanjutnya ditambahkan etanol dengan rasio 10:1 (10 bagian etanol, 1 bagian spora). Campuran dikocok diatas mesin kocok agitasi 250 rpm selama 30 menit, selanjutnya disaring, filtrate ditampung, residu diekstrak kembali dengan etanol $95 \%$ sampai ekstrak tidak berwarna. Filtrate disatukan, kemudian diuapkan etanolnya menggunakan rotary vacuum evaporator. Ekstrak pekat ditimbang untuk mengetahui rendemennya dan disimpan di lemari pendingin sebelum dilakukan mikroenkapsulasi.

\section{Mikroenkapsulasi Ekstrak Etanol}

$$
\text { Mikroenkapsulasi dilakukan }
$$
menggunakan metode pengering beku. Perlakuan yang diterapkan adalah rasio maltodekstrin terhadap ekstrak etanol spora kapang oncom merah yang terdiri atas 4 tingkatan rasio, masing-masing 1:0,5 (A), 1:0,75 (B), 1:1 (C), dan 1:1,25 (D). Campuran maltodekstrin-ekstrak diaduk dan disimpan dalam lemari pendingin, kemudian dikering-bekukan. Mikrokapsul yang dihasilkan, dianalisis aktivitas antioksidannya dan disimpan pada suhu ruang selama empat minggu.

\section{Pengujian Aktivitas Antioksidan mikrokapsul dengan Metode DPPH (Pratiwi et al., 2010)}

Ekstrak etanol dan mikrokapsul ditimbang sebanyak $25 \mathrm{mg}$ dan dimasukkan ke dalam labu ukur $25 \mathrm{ml}$, kemudian ditambahkan etanol, dan ditepatkan volumenya sehingga diperoleh konsentrasi 1000 ppm sebagai larutan stok. Larutan stok diambil $10 \mathrm{ml}$ dengan pipet volum, kemudian dimasukkan ke dalam labu ukur $100 \mathrm{ml}$ dan ditambahkan etanol sehingga diperoleh larutan konsentrasi 100 ppm. Larutan ini diencerkan dalam labu ukur $100 \mathrm{ml}$ untuk menghasilkan larutan dengan konsentrasi 
masing-masing 10 ppm, 30 ppm, 50 ppm, 70 ppm dan 90 ppm. Penentuan aktivitas antioksidan masing-masing konsentrasi dipipet sebanyak 0,2 $\mathrm{ml}$ larutan sampel dengan pipet mikro dan dimasukkan ke dalam vial, kemudian ditambahkan 3,8 ml larutan DPPH 50 uM. Campuran dihomogenkan dan dibiarkan selama 30 menit ditempat gelap, serapan diukur dengan spektrofotometer UV-VIS pada panjang gelombang $517 \mathrm{~nm}$. Selain itu, dilakukan pula pengukuran serapan pada DPPH 50 uM sebagai control. Aktivitas antioksidan yang dinyatakan dalam satuan persen inhibisi dihitung menggunakan persamaan berikut :

$$
\% \text { inhibisi }=\frac{A_{k}-A_{s}}{A_{k}} \times 100 \%
$$

Keterangan: $A_{k}=$ absorbansi DPPH $50 u M$ $A_{s}=$ Absorbansi sampel uji

Nilai $\quad \mathrm{IC}_{50}$ atau Inhibitor Concentration 50\% (menggambarkan besarnya konsentrasi senyawa uji yang dapat menangkap radikal sebesar 50\%) masing-masing konsentrasi sampel dihitung menggunakan rumus persamaan regresi linier yang diperoleh dari kurva hubungan antara persen inhibisi terhadap konsentrasi sampel.

\section{Pengujian Stabilitas Mikrokapsul Ekstrak Etanol}

Penetuan stabilitas menggunakan metode Pratiwi et al. (2010) dengan beberapa modifikasi, Mikrokapsul dari rasio $1: 0,5,1: 0,75$ dan rasio $1: 1$ serta ekstrak etanol yang belum dikapsulasi disimpan masing-masing 1, 2, 3 dan 4 minggu, ditimbang sebanyak $25 \mathrm{mg}$ dan dimasukkan ke dalam labu ukur $25 \mathrm{ml}$, kemudian ditambahkan etanol, dan ditepatkan volumenya sehingga diperoleh konsentrasi 1000 ppm. Untuk penentuan aktivitas antioksidan dalam hal ini persen inhibisi, masing-masing dipipet sebanyak $0,2 \mathrm{ml}$ larutan sampel dengan pipet mikro dan dimasukkan ke dalam vial, kemudian ditambahkan 3,8 ml larutan DPPH 50 uM. Campuran dihomogenkan dan dibiarkan selama 30 menit ditempat gelap, serapan diukur dengan spektrofotometer UV-VIS pada panjang gelombang $517 \mathrm{~nm}$. Selain itu, dilakukan pula pengukuran serapan pada DPPH 50 uM sebagai control. Aktivitas antioksidan yang dinyatakan dalam satuan persen inhibisi dihitung menggunakan persamaan berikut :

$$
\% \text { inhibisi }=\frac{A_{k}-A_{s}}{A_{k}} \times 100 \%
$$

Keterangan: $A_{k}=$ absorbansi DPPH 50 uM $A_{s}=$ Absorbansi sampel uji

\section{HASIL DAN PEMBAHASAN}

\section{Aktivitas Antioksidan Mikrokapsul Ekstrak Etanol Kapang Oncom Merah}

Aktivitas antioksidan mikrokapsul ekstrak etanol kapang oncom merah dilakukan menggunakan metode DPPH dengan spektrofotometri UV-Vis pada panjang gelombang $517 \mathrm{~nm}$. Hasil pengukuran menunjukkan bahwa persen inhibisi meningkat dengan meningkatnya konsentrasi mikrokapsul ekstrak etanol spora kapang oncom merah. Peningkatan 
tersebut tidak sebanding dengan peningkatan konsentrasi. Pada penggunaan konsentrasi $10 \mathrm{ppm}$ nilai persen inhibisinya adalah 9,58\% untuk ekstrak etanol dan $11,17 \%$ untuk mikrokapsul rasio maltodekstrin/ekstrak 1 : 0,5 (b/v), sedangkan kenaikan konsentrasi menjadi 30 ppm hanya meningkatkan persen inhibisi dari $9,58 \%$ menjadi $12,81 \%$ (kenaikan 3,23\%) dan dari 11,17 menjadi 13,50\% (kenaikan 2,33\%) (Tabel $1)$.

Tabel 1. Persen inhibisi mikrokapsul ekstrak etanol spora kapang oncom merah pada berbagai konsentrasi

\begin{tabular}{cccccc}
\hline $\begin{array}{c}\text { Konsen- } \\
\text { trasi } \\
\text { mikro- } \\
\text { kapsul } \\
\text { (ppm) }\end{array}$ & \multicolumn{4}{c}{$\begin{array}{c}\text { Persen inhibisi mikrokapsul pada rasio } \\
\text { maltrodekstrin/ekstrak etanol (b/v) }\end{array}$} \\
\cline { 2 - 6 } & Kontrol & $1: 0,5$ & $1: 0,75$ & $1: 1$ & $1: 1,25$ \\
10 & 9,58 & 11,17 & 5,77 & 4,93 & 4,93 \\
30 & 12,81 & 13,50 & 7,45 & 5,12 & 5,59 \\
50 & 19,60 & 14,34 & 10,34 & 7,64 & 6,42 \\
70 & 22,14 & 14,80 & 11,82 & 9,78 & 7,54 \\
90 & 25,76 & 15,55 & 13,04 & 12,1 & 9,22 \\
\hline
\end{tabular}

Jika kenaikan persen inhibisi sebanding dengan kenaikan konsentrasi, maka untuk ekstrak etanol seharusnya $28,74 \%$ dan untuk rasio $1: 0,5$ (b/v) seharusnya $33,51 \%$. Kenaikan yang tidak sebanding tersebut juga ditemukan oleh Asma (2016) yang pada penggunaan konsentrasi ekstrak etanol spora kapang oncom merah 10 ppm menghasilkan persen inhibisi $8,644 \%$ naik menjadi 9,533\% pada penggunaan konsentrasi 30 ppm. Menurut Huang et al. (2005) faktor penyebab tidak sebandingnya kenaikan nilai persen inhibisi terhadap kenaikan konsentrasi adalah laju reaksi penangkapan radikal DPPH yang tidak sebanding antara kenaikan laju reaksi dengan kenaikan konsentrasi.

Menurut Blois (1985) dalam Molyneux (2004) aktivitas antioksidan dapat dibagi menjadi beberapa kategori berdasarkan nilai $\mathrm{IC}_{50}$, yaitu sangat kuat, kuat, sedang, lemah dan sangat lemah. Antioksidan berkategori sangat kuat memiliki nilai $\mathrm{IC}_{50}<50$ ppm, kuat memiliki nilai $I_{50}$ antara 50-100 ppm, sedang memiliki nilai $\mathrm{IC}_{50}$ antara $100-150 \mathrm{ppm}$, lemah memiliki nilai $I_{50}$ antara $150-200$ ppm, dan sangat lemah memiliki nilai $I_{50}$ > 200 ppm. Berdasarkan hal itu, maka antioksidan mikrokapsul ekstrak etanol spora kapang oncom merah termasuk kategori sangat lemah, sebab nilai $I_{50}$ lebih besar dari 200 ppm atau 203,58 ppm dengan persamaan regresi $\mathrm{y}=208 \mathrm{x}+$ 7,553 .

\section{Stabilitas Mikrokapsul}

Stabilitas karoten yang disalut dengan maltodekstrin terhadap lingkungan (pengaruh cahaya, oksigen dan pengaruh panas), menunjukkan bahwa hasil analisis persen inhibisi setiap minggu adanya perubahan aktivitas antioksidan dari minggu keminggu yang dicirikan dari perubahan persen inhibisi, terutama yang tidak dimikroenkapsulasi.

Ekstrak etanol spora kapang oncom merah konsentrasi 1000 ppm menghasilkan persen inhibisi $80,14 \%$ pada 
minggu pertama, kemudian menurun menjadi $61,63 \%$ pada minggu ke empat atau terjadi penurunan sebesar $18,51 \%$. Persentasi penurunan inhibisi dari minggu pertama adalah $(18,51 / 80,14) \times 100 \%=$ $23,10 \%$, sementara yang tersalut maltodekstrin dengan rasio maltodekstrin/ekstrak etanol 1 : 0,5: 1 : 0,75 dan $1: 1(\mathrm{~b} / \mathrm{v})$ antara minggu pertama dengan minggu keempat masing-masing $10,61 \%$, 10,84\% dan 10,83\%; yang menunjukkan relatif tidak ada penurunan aktivitas antioksidan dan juga tidak dipengaruhi oleh banyaknya ekstrak yang disalut relative terhadap jumlah penyalut (Tabel 2).

Tabel 2. Persen inhibisi mikrokapsul ekstrak etanol spora kapang oncom merah pada berbagai waktu simpan suhu ruang.

\begin{tabular}{ccccc}
\hline \multirow{2}{*}{$\begin{array}{c}\text { Waktu } \\
\text { simpan } \\
\text { (minggu) }\end{array}$} & \multicolumn{3}{c}{$\begin{array}{c}\text { Persen inhibisi mikrokapsul pada } \\
\text { rasio maltodekstrin/ekstrak etanol } \\
\text { spora kapang }\end{array}$} \\
\cline { 2 - 5 } & Kontrol & $1: 0,5$ & $1: 0,75$ & $1: 1$ \\
\hline 1 & 80,11 & 56,48 & 57,38 & 59,02 \\
2 & 76,13 & 54,10 & 55,95 & 57,63 \\
3 & 68,98 & 52,08 & 52,64 & 53,11 \\
4 & 61,63 & 50,49 & 51,16 & 52,63 \\
\hline
\end{tabular}

Data tersebut juga mengkonfirmasi bahwa maltodekstrin sebagai penyalut mampu menurunkan tingkat kerusakan karotenoid pada penyimpanan suhu ruang.

\section{KESIMPULAN}

Rasio maltodekstrin terhadap ekstrak etanol spora kapang oncom merah yang menghasilkan mikrokapsul dengan aktivitas antioksidan yang tinggi terdapat pada rasio $1: 1(\mathrm{~b} / \mathrm{v})$. Mikrokapsul ekstrak etanol spora kapang oncom merah memiliki stabilitas lebih baik dibandingkan dengan ektrak etanol tanpa mikroenkapsulasi pada penyimpanan suhu ruang.

\section{UCAPAN TERIMAKASIH}

Terima kasih yang sebesar-besarnya penulis ucapkan untuk Dewi Indriani S.Si atas seluruh bantuannya untuk penulis.

\section{DAFTAR PUSTAKA}

Asma. 2016. Karakterisasi Dan Uji Aktivitas Antioksidan Ekstrak Konidia Kapang Oncom Merah (Neurospora sp). [Skripsi]. Palu: FMIPA UNTAD.

Gusnidar, T., M. Singgih, Sri Priatni, Sukmawati, dan Tri Suciati. 2011. Enkapsulasi dan Stabilitas Pigmen Karotenoid dari Neurospora Intermedia N-1. J. Manusia dan Lingkungan. 18(3) : 206 - 211.

Hesseltine, C.W. 1961. Proceeding of Conference on Sogbean Products for Protein in Human Food. Peoria.

Huang, D., Ou, B., and Prior, R. L. 2005. The chemistry behind antioxidant capacity assays. Journal of Agriculture and Food Chemistry, 53: 1841-1856.

Kusbandari A, dan Susanti H. 2017. Kandungan Beta Karoten Dan Aktivitas Penangkapan Radikal Bebas Terhadap Dpph (1,1-difenil 2pikrilhidrazil) Ekstrak Buah Blewah (Cucumis melo var. Cantalupensis L) Secara Spektrofotometri Uv-Visibel. JURNAL FARMASI SAINS DAN KOMUNITAS, 14(1): 37-42. doi: http://dx.doi.org/10.24071/jpsc. 14156 2 
Kenyamu M, Mappiratu, dan Nurakhirawati. 2014. Kajian Waktu Simpan Karoten Kapang Oncom Merah (Neurospora sp) Yang Diproduksi Pada Media Tongkol Jagung. Natural Science: Journal of Science and Technology. 3(2): 6269.

Mappiratu. 1990. Produksi beta karoten pada limbah cair tapioka dengan kapang Oncom merah. [Tesis]. Bogor: FPS-Institut Pertanian Bogor.

Molyneux, P. 2004. The use of the stable free radical diphenylpicryl-hydrazyl (DPPH) for estimating antioxidant activity. Songklanakarin J. Sci. Technol., 26(2): 211-219.

Pratiwi, P., M Suzery, dan B Cahyono. 2010. Total Fenolat Dan Flavonoid
Dari Ekstrak Dan Fraksi Daun Kumis Kucing (Orthoshipon stamineus B.) Jawa Tengah Serta Aktivitas Antioksidannya. Jurnal Sains \& Matematika. 18 (4) : 140-148.

Saono, S., Hull, RR., and Dhamcharee, B. 1986. A concise Hand Book of Indigenous Fermented Food in The ASCA Countries. Jakarta, Indonesia: LIPI.

Yuan, Y., Y.Gao, J. Zhao, and L. Mao. 2008. Characterization and stability evaluation of beta carotene nanoemulsions prepared by high pressure homogenization under various emulsifying conditions. Food Research International. 41: 61-68 